\title{
EFFECT OF FOUR BIOACTIVE COMPOUNDS SEPARATELY AND IN COMBINATION WITH CHECKED Metarhizium anisopliae ON THE ACTIVITY OF SOME HAEMOLYMPH ENZYMES OF Schistocerca gregaria (FORSKAL). \\ Farrag, A. A. ;T. A. Abd- Elfattah ${ }^{2}$; G. M. Abdelatef ${ }^{2}$ and \\ M. Kh. El - Dydamony ${ }^{\star}$ \\ 1-EIAzharUniversity, Faculty of science, Microbiology Dep. \\ Madent Nasr, Cairo \\ 2-Plant Protection Research Institute, locust and \\ Grasshopper Research Dep.Doki, Giza. \\ *khyri_dedo@yahoo.com
}

\begin{abstract}
The effect of Metarhizium anisopliae var.acridum and four bioactive compounds (Neem,L- Glutamic acid,Schinusmolle and abamectin) in sole treatments and in combination with $M$. anisopliae var.acridum was studied on activity of Lactate Dehydrogenase Trehalase, Phenol oxidase, and Acid Phosphates in $5^{\text {th }}$ nymphal instar haemolymph of desert locust. Obtained results showed that the integration of $M$. anisopliae var. acridumand the Four bioactive compounds caused $100 \%$ mortality after six days post treatments, also caused severe reduction in activity of all studied enzymes. $M$ anisopliae var.acridum treatment caused significant reduction in Lactate Dehydrogenase by the second day after treatment, but all treatments caused significant reduction in Lactate Dehydrogenase by $4^{\text {th }}$ day post treatment except Neem. In case of trehalase all treatments were significantly lower than control treatment except abamectin two days post treatment, but by day four all treatments were lower than control, while in the $6^{\text {th }}$ day post treatment S. molle, L- Glutamic acid and Neem treatments caused significant increase in Trehales activity. All treatments caused significant increase in Phenol oxidase activity two days post treatment except L- Glutamic acid and abamectin treatment, while after four days Neem and M.var.acridum treatment were still higher than control, but other treatments were significantly lower than control treatment, by the $6^{\text {th }}$ day post treatment only LGlutamic acid caused significant increase in Phenol oxidase activity. In the situation of Acid phosphatase activity two days post treatment abamectin , L- Glutamic acid and M. anisopliaevar.acridum + L- Glutamic acid were significantly lower than control, while after four days all treatments were significantly lower than control, after sex days post treatment only M.anisopliaevar.acridum and L- Glutamic acid were lower than control

Keywords: Schistocerca gregaria, Metarhizium anisopliae, plant extract, amino acid, L- Glutamic acid, Schinus molle, abamectin, Lactate dehydrogenase, trehalese, Phenol oxidase, and acid phosphatase.
\end{abstract}

\section{INTRODUCTION}

Control of desert locusts has traditionally relied on synthetic insecticides, preventive, integrated control strategies with early interventions will reduce the financial coast and environmental hazards associated with large-scale plague treatments, Metarhizium biopesticide kills $70 \%-90 \%$ of treated locusts within 14-20 days, with no measurable impact on non-target 
organisms (Lomer et al., 2001). These products act slowly and are thus inappropriate for emergency situations. However, they should have a role in an integrated control strategy alongside classic insecticides (Lomeret al., 1999). Many studies were done to evaluate the ability of $M$. anisopliae var. acridum to integrate with its other control agents in order to increase efficacy of M.anisopliae var. acridum for desert locust control operations i.e .integration with some insect growth regulators (IGRs) and antifeedant (ElGamal et al., 2004), and with abamectin and D-limonene (Mohamed et al., 2014). S. molle or pepper tree, is an interesting plant that has been used worldwide as an insecticide, however different authors have evaluated the effect of S. molle extracts on varied pests, both important on crops and forests (Abdel-Sattar et al., 2009 and Lópezet al., 2014). L-Glutamic acid is known as excitatory transmitter at the neuromuscular junction of invertebrates (Cull-candy,1976 and Wafford and Sattelle, 1989), while (Clements and May, 1974) showed that when Schistocerca gregarinerve-muscle exposed to glutamate caused a variety of responses, some of which were shown to be abnormal and were much more severely affected.

Insect phenoloxidase is considered an important mediator in defense reaction against pathogens and parasites. It is present in the hemolymph of most insects as an inactive proenzyme, called prophenoloxidase (Da Silva 2002).

Acid phosphatase (AcP) is hydrolytic enzymes, which hydrolyse phosphomonoesters under acid conditions (Bai et al., 1993). AcP may have a role in autophagy and cell turn over as well as defence, Phagocytosis is known to stimulate production of lysosomal enzymes of which AcP is a key component (Xia et al., 2000).

The aim of present study is to evaluate the effect of four bio active agents namely: Neem, S. molle, Abamectin (Aba.) and L-Glutamic acid also the fungus $M$. anisopliae var. acridum(M.) isolate (IMI330189), as well as their mixture with M.anisopliae var. acridum on activity of Lactate dehydrogenase and Trehalase of treated desert locust.

\section{MATRIALS AND METHODS}

\section{Desert locust nymphs}

Fifth nymphal instar of $S$. gregaria two days after final molting, were obtained kindly from desert locust colony maintained in Locust and Grasshoppers Research Dep., Plant Protection Research Institute, ARC, Egypt. Desert locust individuals were reared in the laboratory according to (Robert et al., 2002). The colony was fortified with wild insect collect from the field each year.

\section{Metarhizium anisopliae var.acridum}

The entomopathogenic fungus used during the study is $M$. anisopliae var. acridum isolate (IMI330189) was kindly obtained from BASF Company , South Africa ,under the commercial name Green Muscle ${ }^{\circledR}$. The spores were suspended in sterilized water; trace of Tween (80) was added. The 
concentration was adjusted to $5 \times 10^{8}$ spores/ $\mathrm{ml}$, each nymph received $5 \mu \mathrm{l}$ of the final solution.

Neem (Azaderachtin)

Azaderachtin, under the commercial name Safe-oil $0.03 \%$ EC, at concentration of $1 \mathrm{ml} /$ liter distilled water.

\section{Schinus molle extract}

$50 \mathrm{~g}$ of fresh aerial part of $S$. molle, were air-dried at lab temperature, dried in oven at $40^{\circ} \mathrm{C}$ till constant weight then ground to fine powder, add to $800 \mathrm{ml}$ liter of distilled water in volumetric flask for 3 days and repeated 4 times, then filtrated. Combined filtrates were evaporated under reduced pressure using rotary evaporator apparatus until a minimum amount of solvent remained which gives $(3 \mathrm{~g})$ at last. The extract (brownish sticky) was stored in a refrigerator at $5{ }^{\circ} \mathrm{C}$ and kept for using in different analysis. The concentration used was $1 \mathrm{~g}$ from extract added to $100 \mathrm{ml}$ distilled water (Woo et al., 1977).

Amino acid (L-Glutamic acid)

Molare solution from L-glutamic acid is prepared by addition of $147.13 \mathrm{gm} \backslash$ litter distilled water. concentration are used is 0.1 from molar solution (Krasilnikov and Bakhramov, 1983) each nymph received $5 \mu$ l of the final solution.

Abamectin

5-O-demethylavermectin $\mathrm{A}_{1 \mathrm{a}}$ (i) mixture with 5-O-demethyl-25-de(1methylpropyl)-25-(1-methylethyl) avermectin $A_{1 a}$ (ii).Under the commercial name, Agromic $1.8 \% \mathrm{EC}$, was used at concentration of $1 \mathrm{ml} /$ liter distilled water, each nymph received $5 \mu$ l of the final solution.

\section{Mixtures}

Metarhizium anisopliae var.acridum was used in combination with Neem, S. molle, L-Glutamic acidand Abamectin, mixture solution contain the same concentration for each infeluintal in alone case.

\section{Treatments}

Ten $5^{\text {th }}$ instar nymphs were used in each treatment. M. anisopliae var.acridum, L-glutamic acid and Abamectin treatments were used as topical application, while Neem and $S$. molle were used as follow: $20 \mathrm{~g}$ of fresh clover were dipped in $100 \mathrm{ml}$ of each used concentration, dried for $1 \mathrm{hr}$. in room temperature, then introduced to the nymphs. The mixtures were used as topical application, but in case of Neem and $S$. molle the nymphs were treated with $M$. anisopliae var. acridum first then were feed on treated clover as described previously.

\section{Haemolymph Sample collection}

The haemolymph was collected through a fine puncture in the hind leg and from beneath the dorsal pronotal shield membrane and transferred into dry centrifuge tubes (Metaweh et al., 2001), at days 2, 4 and 6 post treatments.

Estimation activity of Lactate Dehydrogenase Enzyme (LDH):

Activity of Lactate Dehydrogenase was estimated according to German Society for Clinical Chemistry (DGKC, 1972). NADH is oxidized to NAD. The rate of NADH decrease is directly proportional to the LDH activity and is determined photometrical. The reaction mixture consisted of 
phosphate buffer $(68 \mathrm{~m} / \mathrm{mol} / \mathrm{L}, \mathrm{pH} 7.5)$, pyruvate $(0.73 \mathrm{~m} / \mathrm{mol} / \mathrm{L})$ and $\mathrm{NADH}$ $(1.1 \mathrm{~m} / \mathrm{mol} / \mathrm{L})$. Heamolymph $(100 \mu \mathrm{L})$ was mixed with the mixture $(2.5 \mathrm{ml})$ that pre-incubated at $37^{\circ} \mathrm{C}$, then the absorbance was measured by the spectrophotometer at $340 \mathrm{~nm} / \mathrm{min}$.

\section{Estimation activity of Trehalase Enzyme:}

Trehalase activity were determined according to the method described by (Ishaaya and Swirski, 1976), using trehalose, as substrates for trehalase. The enzyme activity was expressed as $\mu \mathrm{g}$ glucose released $/ \mathrm{min} / \mathrm{g}$ fresh weight.

\section{Estimation activity of Phenoloxidase Enzyme:}

Phenoloxidase activity was monitored spectrophotometrically as formation of quinines according to Ishaaya, 1972with some modifications, $200 \mu \mathrm{l}$ haemolymph, $2 \mathrm{ml}$ phosphate buffer $(0.2 \mathrm{M}, \mathrm{pH} 7)$ and $0.5 \mu \mathrm{l} 2 \%$ Catechol were mixed gently, incubated for $5 \mathrm{~min}$ at $25^{\circ} \mathrm{C}$, The activity was then recorded at absorbency $470 \mathrm{~nm}$, the optical density was recorded every $1 \mathrm{~min}$ for $10 \mathrm{~min}$. The specific activity of phenoloxidase was expressed as units of activity per $\mathrm{mg}$ of protein. One unit of activity was defined as the amount of enzyme that increases the absorbance by 0.001 units per min.

\section{Estimation activity of Acid Phosphatase Enzyme:}

For determination of acid phosphates in haemolymph, Powell and Smith (1954) method with slight modification were used, where the hydrolysis of disodium phenylphosphate by acid phosphates releases phenol, which reacts with 4-aminoantipyrine, and by the addition of potassium ferric cyanide a brown color is produced. The produced color was measured, immediately, by spectrophotometer at $510 \mathrm{~nm}$. The optical density was converted to enzymatic activity units which expressed as $\mathrm{mg}$ phenol released/ $\mathrm{ml}$ haemolymph.

\section{Statistical analyses}

Data were subjected to Analyses of Variance using costat 6.4 software from CoHort Software, 2 way completely randomized procedure was utilized.

\section{RESULTS}

Data illustrated in Table (1) showed that, the effect of different treatments on the activity of lactate dehydrogenase in muscle of desert locust, it's clear that the treatment of $S$. molle, M + Neem, M + L- Glutamic acid, L- Glutamic acid and $\mathrm{M}+$ S. molle caused significant increase in the activity of lactate dehydrogenase comparing with control treatment (there values were $971.00,882.67,857.67,721.00$ and 645.33 respectively), while S. molle was significantly higher than $M+$ Neem and $M+$ L- Glutamic acid which were significantly higher than L- Glutamic acid which were higher than $\mathrm{M}+$ S. molle and Neem treatments. There were no significant differences between control treatment and both Abamectin and M+ Abamectin (there values were 548.33 and 556.00 respectively), but the control treatment were significantly higher than $M$ treatment. By day four post treatment the application of Neem caused significant increase in compeer with control. 
While other treatments were significantly lower than control, also M treatment showed the lowest value. By the $6^{\text {th }}$ day post treatment, the treated insects in the mixtures treatments were died, while abamectin showed significant increase in the activity of lactate dehydrogenase than control treatment. There were no significant differences between control and $S$. molle treatments. While other treatments were significantly lower than control.

The obtained result in Table (2) showed the effect of same previous treatments on trehalase activity. The results showed significant increase in trehalse activity than control after 2 days post treatment with abamectin, while such activity in control treatment were significantly higher than other treatments except $M+S$. molle. In case of day 4 post treatment the enzyme activity in control treatment was significantly higher than other treatments. By day 6 post treatment all nymphs treated with mixtures were died. While the enzyme activity in S. molle, L- Glutamic acid and Neem treatments were higher than control treatment (there values were 342.00, 322.67 and 306.67 respectively), but such activity in control treatment were higher than abamectin treatment followed by $M$ treatment.

The obtained result in Table (3) illustrated the effect of the for mentioned bioactive compounds on the activity of Phenoloxidase, 2 days post treatment both Abamectin and L- Glutamic acid caused significant decrease of Phenoloxidase activity than control treatment (there values were 3592.67 and 3569.33respectively), while other treatments were significantly higher than control. By the $4^{\text {th }}$ day post treatment only Neem treatment was significantly higher than control, while $M+$ Neem, M + L- Glutamic acid, treatments did not differ significantly than control (there values were 5480.00 and 5406.33respectively), but the treatments of $\mathrm{M}$ alone, $\mathrm{M}+\mathrm{S}$. molle, $\mathrm{S}$. molle, and L- Glutamic acid were significantly lower than control (there values were $2549.67,2500.00,1390.00$ and1060.66 respectively). L- Glutamic acid treatment caused significant increase in Phenoloxidase than control treatment but other treatments were significantly lower than control.

Data demonstrated in table (4) revealed, activity of acid phosphatase was significantly higher than control 2 days post treatment in $M+A b a$., $M+$ Neem, M, M+S. molle, Neem and $S$. molle treatments (there values were $24.70,25.70,26.70,29.00,30.70$ and 31.70 respectively), while such activity was significantly lower than control, in Aba., M + L- Glutamic acid and LGlutamic acid (there values were $17.33,19.00$ and 22.50 respectively). At day 4 post treatment the activity of acid phosphatase in all treatments were significantly lower than control treatment. By the $6^{\text {th }}$ day post treatment $S$. molle, Abamectin and Neem caused significant increase in acid phosphatase activity than control (there values were 52.33, 52.40 and 48.11respectively), but both L- Glutamic acid, and $\mathrm{M}$ caused significant decrease than control (there values were 31.50 and 24.90 respectively). 
Farrag, A. A. et al. 
J. Plant Prot. and Path., Mansoura Univ., Vol. 6 (6), June, 2015

3-4 


\section{DISCUSSION}

\section{Lactate dehydrogenase:}

Lactate dehydrogenase catalyzes the inter-conversion of pyruvate and lactate with concomitant inter-conversion of NADH and NAD+ in glycolysis cycle (Kaplan and Pesce, 1996). In this study the activity of LDH are decreased than control after 2,4 and 6 days when insect treated with $M$. anisoplaiae this result are in parallel to (Mohamed, 2009) which found decreased in activity of LDH rather than control after1,2 and 3 days when treated S. gregaria with M. anisoplaiae. Sewify and Hashem (2001) reported that, the effect of $M$. anisoplaiae on oxygen uptake of the wax moth Galleria mellonella L.and suggest the decrease in LDH acctivity may be due to the increase the oxygen uptake.

In all other treatment the activity of LDH are increased than control this result are in parallel to (Hamadah et al, 2010) in case of plant extract which treated S. gregaria with plant extract from Fagonia bruguieri and found the activity of $\mathrm{LDH}$ increased than control.

In Since LDH is important enzyme in the carbohydrate metabolism and related to energy production in the living cell, the induced activity level in the haemolymph of nymphs of $S$. gregaria, in the present study, indicates generally an active energy metabolism in this important tissue. It, also, may indicate an effective stimulation of the portion of the Cori cycle responsible for the overall recycling lactate, since this would result in concomitant enhanced production of pyruvate and glucose via glucogenesis (Harper et al., 1984).

\section{Trhalase:}

Trehalse could be used as parameter for assessing the availability of nutrients (Ishaaya and Swirkski, 1976) in this study the activity of trehalase after 2 days from inoculation in all treatments except abamectin and mixture from $M$. anisoplaiae and plant extract from S. molle and in all treatments after 4 days is lower than control, this decrease due to The decreasing in trehalase activity may be due to toxicity stress of the treatments as indicating by many authors (Fahmy and Dahi, 2009, Elbanna et al., 2013 and (Rashwan, 2013). Increase in activity of trehalase after 2 days from inoculation in abamectin are in parallel to (Dahi, et al., 2009) which found increase in activity of trehalase when treated Egyptian cotton leaf worm Spodoptera littoralis with avermectin While the activity is increased after 6 days from infection in case Neem, plant extract from $S$. molle and L- glutamic acid this result are in parallel to (Mohamed, 2014) which treated S. gregaria with Neem and found the activity of trehalase in insect which treated with Neem are higher than control. While in case of insect which treated with abamectin after 6 days the activity of trehalase is lower than control this result are in parallel to (Abo El-Ghar et al. 1995) which found that when feeding Spodoptera littoralis larvae 5 ppm abamectin caused remarkable decrease in trehalase activities.

\section{Phenoloxidase:}

The innate immune system in insects is composed of a large variety of specific and non-specific responses that are activated in response to the presence of foreign agents. One important element in such responses is the 
enzyme phenoloxidase (PO) (Isaac and Alex., 2012) The activity of phenoloxidase are increased when insect infected with Metarhizium anisoplaiae after 2 days from inoculation while after 4 and 6 days the activity of phenoloxidase is decreased which match with (Gabarty et al., 2013). When conidia land on the cuticle of a suitable host, they attach and germinate, initiating cascades of recognition and enzyme activation reactions by both the host and the fungal parasite. The defensive responses to the fungi infection lead to activation of the phenoloxidase and other enzymes of cascade increased levels of phenoloxidase may help to suppress microbial infection during the time interval. (Gillespie et al., 2000b) illustrated that. When insect infect with Metarhizium the hemolymph phenoloxidase are decline over the course of the infection until the death of Schistocerca gregaria.

In all other treatment the activity of phenoloxidase are increased than control after 2 days which indicated that, the insect increase immune response and attack these foreign particles and this result are in parallel to (Isaac and Alex., 2012) which said in invertebrate immunology have documented a complex array of host defenses. These defenses include phagocytosis.

\section{Acid phosphatase:}

Untreated control locusts had constitutive levels of AcP which may have a role in autophagy and cell turn over as well as defense, Phagocytosis is known to stimulate production of lysosomal enzymes of which AcP is a key component (Xia et al., 2000).

In this study after 2 days from infection the activity of acid phosphatase in majority of influential is higher than control this result is in parallel to (Eissa and. Zidan, 2009) which found elevated the activity of acid phosphatase (ACP) when treated Male Albino Rats with abamectin, result which obtained from $M$. anisoplaiae alone and when mixed with Neem, plant extract from $S$. molle and abamectin are parallel to(Xia et al., 2001) which found The AcP activity in haemolymph of mycosed insects increased significantly over controls, this may be due to secreation of ACP from M. anisoplaiae. After 4 days from infection the activity of acid phosphatese is lower than control this result is in parallel to (Kandil et al, 2009) which found inhibition in activity of ACP after three days when infected Land snails with abamectin.

\section{REFERENCES}

Abdel-Sattar, E.,Zaitoun, A.,Farag,M.,El Gayed, S., Harraz,F., 2009.Chemical composition, insecticidal and insect repellent activity of Schinusmolle L.leaf and fruit essential oils against Trogodermagranarium and Triboliumcastaneum. Nat. Prod. Res.25, 1-10.

Abo El-Ghar, G.E.S.; H.S.A. Radwan; Z.A. El- Bermawy and L.T.M. Zidan (1995).Inhibitoryeffect of thuringiensin and abamectin on digestive enzyme and non-specific esterases of Spodopteralittoralis(Boisd.), (Lep.,Noctuidae). J. Appl. Ent. 119: 355-359. 
Bai, C., Yi, S-X.andDegheele, D. 1993. Phosphatases in last instar larvae of the African armyworm, Spodopteraexempta (Walker)(Lepidoptera: Noctuidae). Med.Fac.LandbouwUniv.Gent, 58: 317-327.

Clements, A. T. and May, T. E. (1974).Studies on locust neuromuscular physiology in relation to glutamic acid.J. exp. Biol. 60, 335-378.

Cull-candy S. G. (1976). Two types of extrajunctional I-glutamate receptors in locust muscle fibres. J. Physiol. 255: 449-464.

Dahi H. F.; Y. A. El-Sayed; Nehad M. El-Barkey; and Mona F. Abd-El Aziz . (2009) Toxicological and biochemical studies of Methylamine Avermactin, a new type of bioinsecticide against the cotton leafworm, Spodoptera littoralis (Biosd). Egypt. Acad. J. biolog. Sci.,2 (1):103- 116.

Da Silva, Cleonor C.A. (2002). Activation of Prophenoloxidase and Removal of Bacillussubtilis from the Hemolymph of Achetadomesticus(L.) (Orthoptera: Gryllidae). Neotrop.Entomol. 31:487-491.

DGCK (Deutsch Gesellschaft fur KlinischeChemie) (1972). Mpfehlungender Deutsch Gesellschaft fur KlinischeChemie. J. Clin. Chem. Biochem., 10: 182-193.

Eissa, F.I. and N.A. Zidan (2009). Haematological, Biochemical and Histopathological Alterations Induced by Abamectin and Bacillus thuringiensis in Male Albino Rats. Australian Journal of Basic and Applied Sciences, 3(3): 2497-2505

ElbannaS. M. , N. M. Elhadidy , A.M. Azazy , E.. Elhallous and F. M. Semida (2012).Senergetic effects of bioranza (Metarhiziumanisopliae) and nematode (Steinernemafeltiae) on desert locust (Schistocercagregaria) nymphs. Egyptian Journal of Natural Toxins, 9: 9-22.

El-Gammal A.M; HM. El-Gawhary; Abd El-FattahT.A. and M.T. Mohammed., (2004).Field trials to investigate the spores of Metarhiziumflavoviride as microbial control agent and its Integrated action with some insect growth regulators against Locustamigratoriamigratorioides in Shark ElUwainat area .Egypt . J. Appl. Sci., 19: 255-265.

Fahmy, N. M. and H. F. Dahi.(2009). Changes in detoxifying enzymes and carbohydrate metabolism associated with spinetoram in two fieldcollected strains of Spodopteralittoralis(Biosd.). Egypt. Acad. J. biolog. Sci., 1 (1): $15-26$.

Gabarty, A.; El-Sonbaty, S. M. and Ibrahim, A. A. (2013) Synergistic effect of gamma radiation and entomopathogenic fungi Beauveria bassiana and Metarhizium anisopliae on the humoral immune enzyme response in cotton leaf worm Spodoptera littolaris (Boisd). Egypt. Acad. J. Biolog. Sci., 6(3): $1-10$.

Gillespie, J.P., C. Burnett and A.K. Charnley, 2000b. The immune response of the desert locust Schistocerca gregaria during mycosis of the entomopathogenic fungus, Metarhizium anisopliae var acridum. J. Insect Physiol. 46: 429-437.

Hamadah, Kh. Sh.; Basiouny, A. L. and Ghoneim, K. S. (2010). Alterations in the lactate dehydrogenase activity of the desert locust Schistocerca gregaria by the wild plant Fagonia bruguieri (Zygophyllaceae). Egypt. Acad. J. biolog. Sci., 3 (2): 1-9. 
Harper, A. E., Miller, R. H. \& Block, K. P. (1984). Branched chain amino acid metabolism. Annual Review of Nutrition 4, 409-454.

Isaac González-Santoyo and Alex Córdoba-Aguilar (2012). Phenoloxidase: a key component of the insect immune system. Entomologia Experimentalis ET ApplicataVolume 142, Issue 12, pages 1-16, January 2012.

Ishaaya, I. (1972).Studies of the haemolymph and cuticularphenoloxidase in Spodopteralittoralis larvae. J. Insect Physiol., 2: 409-419.

Ishaaya I, Swriski E (1976). Trehalase, invertase and amylase activities in the black scale, Saissetiaoleae, and their relation to host adaptability.J Insect Physiol22: 1025-1029.

Kandil M.A., El-Deeb H.I, Mobarakand S. A..Eweis E.A (2009) biochemical impacts of methomyl and abamectin and their binary mixtures with acetylsalicylic acid against the land snails Eobania vermiculata and Monacha obstructa. Conference on Recent Technologies in Agriculture, 2009

Kaplan LA, Pesce AJ. (1996)Clinical Chemistry - Theory Analysis and Correlation, Mosby-Year Book, MO.

Krasilnikov and A. Bakhramov (1983).Studies on the Effect of Glutamic, Aspartic and y-Amino Butyric Acids on Locust Muscle Fibre Membrane PotentialGen. Physiol. Biophys. (1983), 2, 133-135.

Lomer C.J., Bateman R.P., Dent D., De Groote H., Douro-Kpindou O.-K., Kooyman C., Langewald J., Ouambama Z., Peveling R., Thomas M. 1999. Development of strategies for the incorporation of biological pesticides into the integrated management of locusts and grasshoppers. Agricultural and Forest Entomology 1, 71-88.

Lomer C.J., Bateman R.P., Johnson D.L., Langewald J., Thomas M. 2001.Biological control of locusts and grasshoppers. Annual Review of Entomology 46 : 667-701.

LópezA., S. Castro b, M.J. Andinaa, X. Ures a, B. Munguíaa, J.M. Llabot b, H. Elder c, E. Dellacassa d, S. Palma b, L. Domínguez a, (2014)Insecticidal activity of microencapsulated Schinusmolle essential oil. Industrial Crops and Products. 53: 209-216.

Metaweh, H.H.; E.A.A Gomaa; R.M.Sherif and Abdelfattah (2001).Bio chemical changes of the haemolymph of the fifth nymphal instar of the grasshopper, Euprepocnemisploransplorans after infection with three entomopathogenic fungi. Egyptian Journal of Biological Pest Control, 11(2), 2001, 177-182.

Mohamed, E. S. 2009 The effect of entomopathogenic fungus Metarhizium anisopliae var. acridum on flight muscle in the desert locust Schistocerca gregaria (Forskal). M. Sc. Thesis, Cairo University

Mohamed, E. S. 2014 Separate and joint action of neem and cascade on the desert locust Schistocerca gregaria (Forskal). Ph. D. Thesis, Cairo University.

Mohamed, Gehan A., Hala M. Ibrahim and G. M. Abdelatef. (2014) Novel pesticides for desert locust Schistocercagregaria(Forskal) control. Journal of Plant Protection and Pathology 5: 1065-1071. 
Powell, M. E. A. and Smith, M. J. H. (1954) The determination of serum acid and alkaline phosphatase activity with 4 Aminotipyrine. J Clin. Pathol., 7:245-251.

Rashwan M. H. (2013).Biochemical Impacts of Rynaxypyr (Coragen) and Spinetoram (Radiant) on Spodopteralittoralis(Boisd.). Nature and Science 11(8).

Robert M. Ouedraogo, Andrena Kamp, Mark S. Goettel, Jacques Brodeur and Michael J. Bidochka (2002). Attenuation of fungal infection in thermoregulatinglocustamigratoria is accompanied by changes in haemolymph proteins. Journal of Invertebrate Pathology 81: 19-24.

Sewify GH, Hashem MY (2001) Effects of the entomopathogenic fungus Metarhizium anisopliae (Metsch.) Sorokin on cellular defence response and oxygen uptake of the wax moth Galleria mellonella L. (Lep., Pyralidae). J Appl Entomol 125: 533-536.

Wafford, K. A. and D. B., Sattelle (1989).L-glutamate receptors on the cell body membrane of an identified insect motor neurone. J. Exp. Biol. 144: 449-462.

Woo, W.S., H.J., Chi, S., Yun and S., Hye (1977). Alkaloid screening of some Saudi Arabian plants. Saengyak Hakhoe Chi (Hanguk SaengyaK Hakhoe), 8(3): 109-113.

Xia, Y.; Dean, P.; Judge, A. J.; Gillespie, J. P.; Clarkson, J. M. and Charnely, A. K. (2000). Acid phosphatase in the haemolymph of desert locust, Schistocercagregaria infected with the entomopathogenic fungus, Metarhiziumanisopliae. Journal of Insect Physiology, 46:1249 -1257.

Xia, X., Qian, S., Soriano, S., Wu, Y., Fletcher, A. M., Wang, X. J., Koo, E. H., $\mathrm{Wu}, \mathrm{X}$. and Zheng, H. (2001). Loss of presenilin 1 is associated with enhanced b-catenin signaling and skin tumorigenesis. Proc. Natl. Acad. Sci. USA 98, 10863-10868. 
تـأثير اربـع مركبـات ذات نشـاط حيـوي منفـردة او مخلوطـه مـع فطر الميتـاريزيم

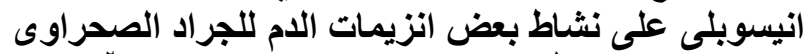

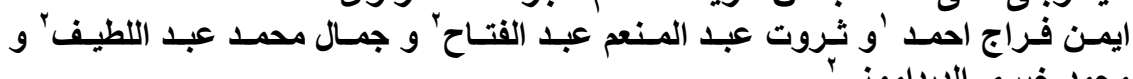

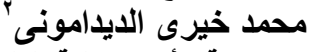

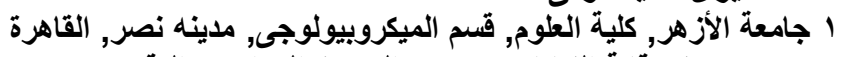

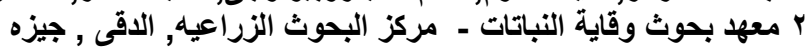

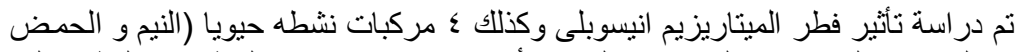

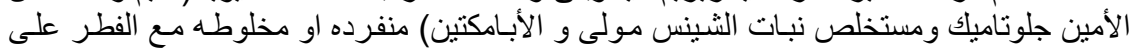

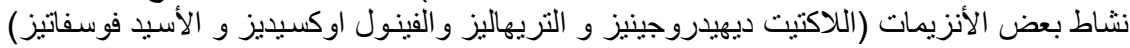

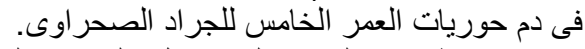

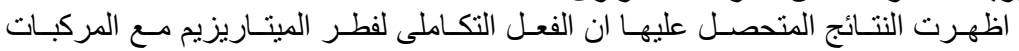

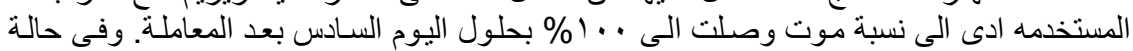

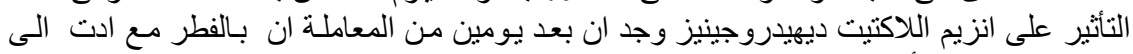

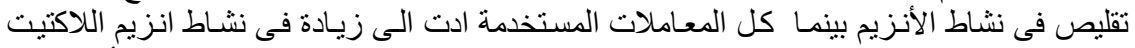

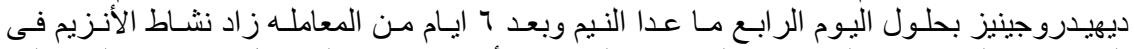

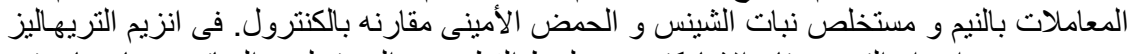

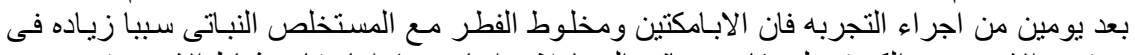

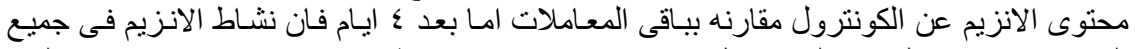

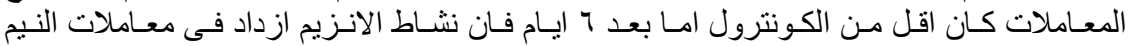

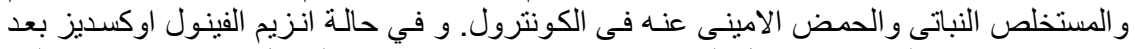

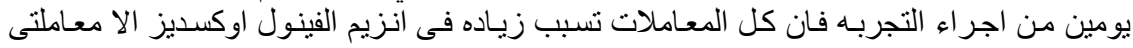

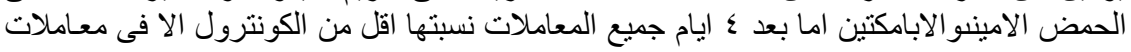

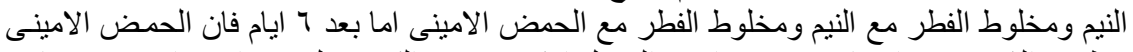

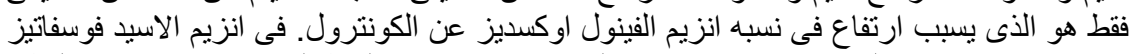

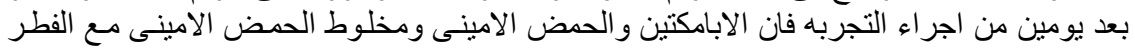

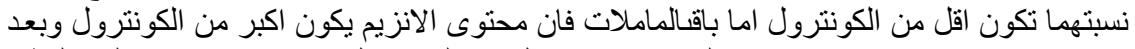

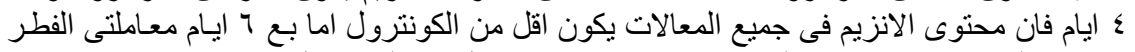
منفردا و الحمض الامينى هما الذان يكون محتوى الانزيم اقل من الكونترول. 


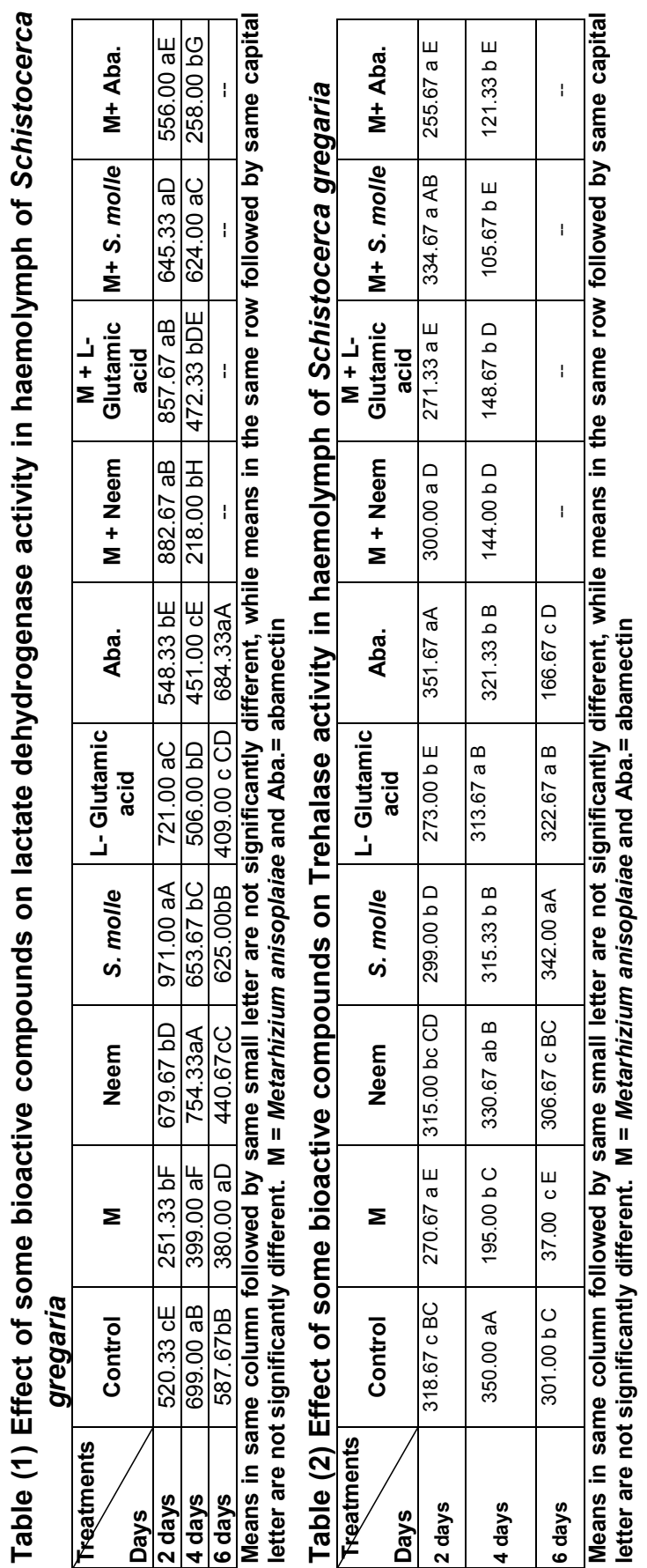



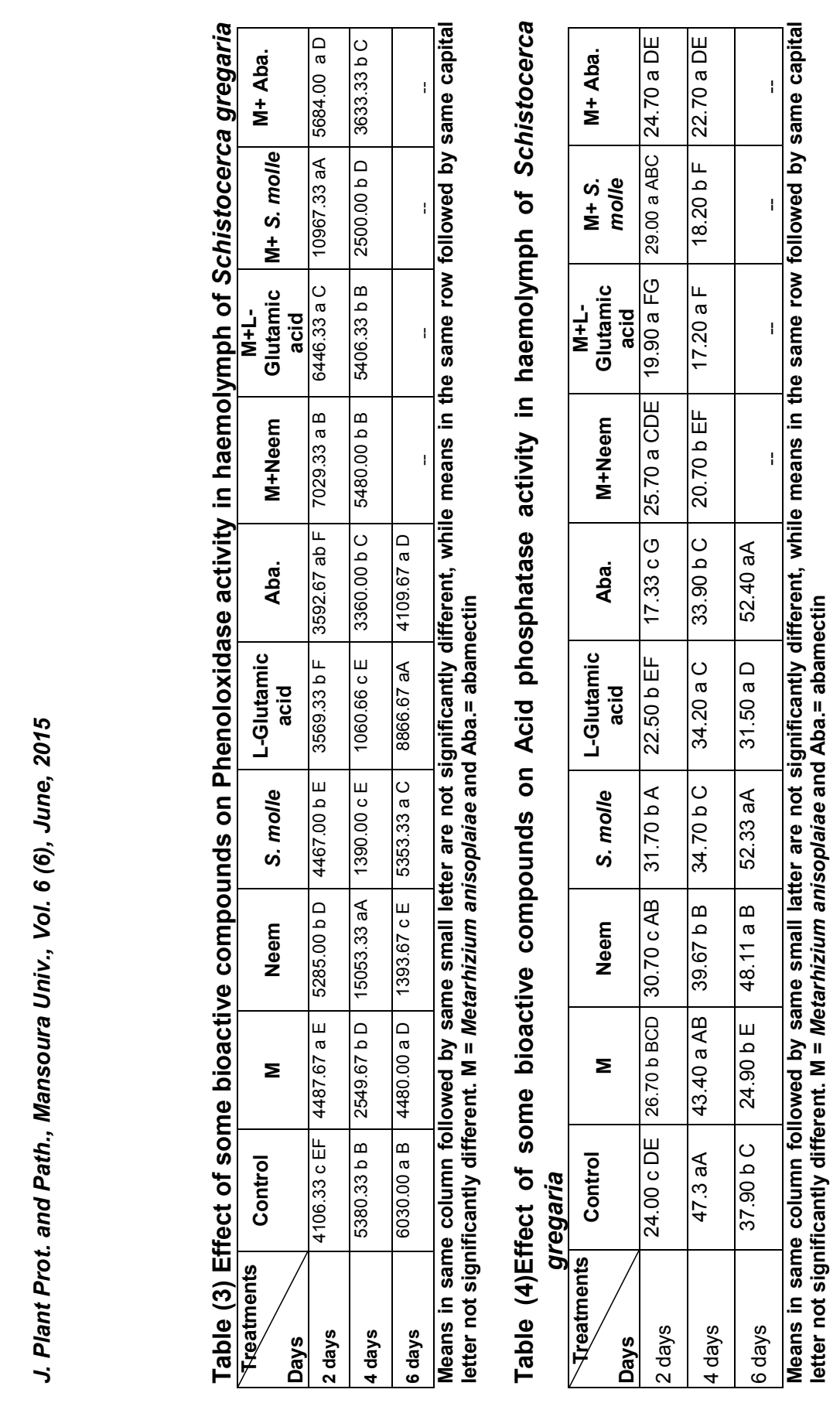

$\infty$
$\infty$
$\infty$ 